\title{
RESPONSE OF GRAPEVINE LEAVES TO PLASMOPARA VITICOLA INFECTION BY MEANS OF MEASUREMENT OF REFLECTANCE AND FLUORESCENCE SIGNALS
}

\author{
D. Šebela, J. Olejníčková, A. Župčanová, R. Sotolář
}

Received: September 13, 2012

\begin{abstract}
ŠEBELA, D., OLEJNÍČKOVÁ, J., ŽUPČANOVÁ, A., SOTOLÁŘ, R.: Response of grapevine leaves to Plasmopara viticola infection by means of measurement of reflectance and fluorescence signals. Acta univ. agric. et silvic. Mendel. Brun., 2012, LX, No. 8, pp. 229-238

Response of grapevine leaf tissue naturally infected by Plasmopara viticola in field was measured by means of chlorophyll fluorescence and reflectance signals. Three susceptible grapevine varieties (Cabernet Sauvignon, Pinot Blanc and Pinot Gris) were used in this study. Since the infection impairs photosynthetic activity, distribution of $\mathrm{F}_{\mathrm{V}} / \mathrm{F}_{\mathrm{M}}$ parameter (maximum quantum yield of Photosystem II) over the leaf was effective to discriminate healthy and naturally infected leaf tissue. $\mathrm{F}_{\mathrm{V}} / \mathrm{F}_{\mathrm{M}}$ was reduced $\sim 25 \%$ in all infected leaf parts. Infected leaf spots expressed significantly altered chlorophyll fluorescence induction kinetics expressing much slower electron transport rate both on donor and acceptor site of PSII. Vegetation reflectance indices followed the variations in pigment content after the fungal infection. $\mathrm{R} 750 / \mathrm{R} 700\left(\mathrm{R}^{2}=0.877\right)$ and $\mathrm{CRI}$ (carotenoid reflectance index; $\mathrm{R}^{2}=0.735$ ) were the most potent to follow changes in chlorophylls and carotenoids contents, respectively. Infected leaf tissue exhibited decrease in chlorophyll a ( $\sim 50 \%)$ as well as carotenoids ( $70 \%)$. We conclude that combination of chlorophyll fluorescence and reflectance measurements can be used as an effective non-invasive tool for an early detection of Plasmopara viticola in field as well as for estimation of the level of infection.
\end{abstract}

Plasmopara viticola, downy mildew, grapevine, leaf tissue, susceptible varieties, chlorophyll fluorescence imaging, reflectance

\footnotetext{
Abbreviations

Car........ carotenoids

CRI ........ carotenoid reflectance index

CCD ..... charge coupled device

Chl........ chlorophyll

Chl-F.... chlorophyll fluorescence

$\mathrm{F}_{0}$............ minimum chlorophyll fluorescence yield in dark - adapted state

$\mathrm{F}_{\mathrm{M}}$ …....... maximum chlorophyll fluorescence yield in dark - adapted state

$F_{\mathrm{p}}$........... peak chlorophyll fluorescence yield measured when the actinic light is switched on, it is measured after ca ls of actinic light

$\mathrm{F}_{\mathrm{S}}$............ steady state chlorophyll fluorescence yield in light - adapted state
}

$\mathrm{Fd} / 2=(\mathrm{FP}-\mathrm{FS}) / 2$

LED ...... light emitting diode

PSII ...... photosystem II

VI........... reflectance vegetation index

Grape vine (Vitis vinifera L. subsp. vinifera Hegi, 1753) has many potential pests, which may cause decreases, or in the most serious cases complete yield destruction if no chemicals are applied. One of the major diseases of the grapevine is downy mildew [Plasmopara viticola (Berk. \& Curtis ex de Bary) Berlese \& de Toni, 1888]. Plasmopara viticola is the casual agent of grape downy mildew (e.g. Kortekamp and Zyprian, 2003). It is an obligate biotrophic oomycete that grows in the intercellular spaces 
of host tissues and develops haustoria in the cells (Diez-Navajas et al., 2006). Occurrence of oomycete downy mildew depends mostly on climate; for the infection spreading is necessary frequent rain, wet during vegetative growth of vine (e.g. Lafon and Clerjeau, 1988) and cool climates (optimum 20-25 ${ }^{\circ} \mathrm{C}$ ). Plasmopara viticola attacks all parts of the plants (e.g. flowers, grapes), but mostly leaves. Symptoms of infection typically appear as areas of yellowish green oily spots in different size. The spots are large, irregular and bounded. They appear ca 7 days after infection (Cséfalvay et al., 2009). In wet weather, on the abaxial part of the leaves, white coating of sporangia and mycelium appears. Spots gradually turn brown, chlorotic and become necrotic, mostly delimited by the main veins, which are accompanied by profuse sporulation (Lebeda et al., 2008).

Usually, biological interaction between plant and pathogen results in alternation of several physiological processes of the host plant, resulting in changes in carbon metabolism and primary photosynthesis, followed by changes in pigment composition (e.g. Mandal et al., 2009; Rolfe and Scholes, 2010; Moriondo et al., 2005). All such metabolic changes affect optical properties of the leaves.

Optical signals of the plants have been frequently used for pre-symptomatic detection of biotic stress of plants (e.g. Romer et al., 2011; Cséfalvay et al., 2009). Chlorophyll fluorescence emission (Chl-F) is undoubtedly one of the most powerful optical signals that non-invasively reports on the processes of light capture and its photosynthetic use thanks to its close relationship with photosynthesis (e.g. Papageorgiou and Govindjee, 2011; Bjorn et al., 2009; Roháček et al., 2008). Chl-F is not a static variable. Simply stated, Chl-F yield is the highest, when photochemistry is the lowest; and vice versa. When dark - adapted healthy leaf is exposed to actinic light, the induced Chl-F displays characteristic changes in its intensity accompanying the induction of photosynthetic activity (e.g. Papageorgiou et al., 2011). The interpretation of Chl-F signals has been reviewed in a number of detailed papers and books (e.g. Papageorgiou and Govinjee, 2004; Roháček, 2002; Maxwell and Johnson, 2000), as well as Chl-F has been frequently used for an early detection of the various infections before the occurrence of visible symptoms (e.g. Rolfe, 2010; Cséfalvay et al., 2009; Nedbal and Whitmarsh, 2004; Barbagallo et. al., 2003). Distribution of Ch-F emission over the grapevine leaves has been successfully used for pre-symptomatic detection of Plasmopara viticola infection (Cséfalvay et al., 2009). Here, as the most sensitive reporters of the Plasmopara viticola infection were identified maximum $\left(\mathrm{F}_{\mathrm{V}} / \mathrm{F}_{\mathrm{M}}\right)$ and effective $\left(\Phi_{\mathrm{PSI}}\right)$ quantum yield of photosystem II.

Reflectance signal is predominantly used in remote sensing (e.g. Wu et al., 2008; Blackburn and Ferwerda, 2008). Spectrum of reflected light from the leaf surface is strongly dependent on the physiological state of the plant (e.g. Merzlyak et al., 1997; Ustin et al., 2004). Reflectance, thanks to properties of pigments participated in light absorption provides non-invasive insight to pigment composition of leaves. Essential pigments affecting the optical properties of leaves are chlorophylls (Chl), carotenoids (Car) and plant phenolics. Among others, Chl play indispensable role in capturing the light energy during the primary photosynthesis (e.g. Lodish et al., 2000) and Car play significant role in photoprotection (Davies, 2004).

Spectrum of reflected light in visible light $(400-800 \mathrm{~nm})$ is dominantly characterized by the absorption spectrum of Chl; i.e. high reflectance in green (500-600 $\mathrm{nm}$ ) and minimal reflectance in red region (660-700 nm). Number of vegetation indices (VIs) has been defined from the variation of the reflected light spectrum to calculate concentrations of particular pigments in leaves/canopy (e.g. Blackburn, 2007). The most frequently used VIs for Chl estimation in single leaves are: $R_{750} / R_{550}$ (Gitelson and Merzlyak, 1994), $\mathrm{R}_{750} / \mathrm{R}_{700}$ (Gitelson and Merzlyak, 1994), $\left(\mathrm{R}_{780}-\mathrm{R}_{710}\right) /\left(\mathrm{R}_{780}-\mathrm{R}_{680}\right)$ (Maccioni et al., 2001). Estimation of Car absorbing in blue region is more complicated since it is affected by an overlap of their absorption spectra with those of Chl, and by their relatively low concentration in comparison with Chl. By using terms corresponding to light absorption both for Chl and Car, and term related only to Chl absorbtion, carotenoid reflectance indices CRI (Merzlyak et al., 2003; Gitelson et al., 2002) was designed for Car estimation.

Early information of crop physiology and possible detection of disease in field conditions can lead to effective strategy of wine producer and the resulting proper management. Visualization of the infections, even before they are visible, can be imaged by the heterogeneous optical signals and thus precede their expansion. In this study we have investigated changes in optical signals (Chl-F and particular reflectance indices) of grapevine leaves naturally infected by fungus Plasmopara viticola that can be used for its pre-symptomatic detection in field. We have focused on three susceptible grapevine varieties: Cabernet Sauvignon (CS), Pinot Blanc (PB) and Pinot Gris (PG).

\section{MATERIALS AND METHODS}

\section{Plant material}

Leaves of three susceptible grapevine plants have been sampled in experimental vineyard (Department of Viticulture and Oenology, Lednice, Czech Republic, 4847'24.16"N; 16²7'53.61"E), on $17^{\text {th }}$ July 2011. Healthy and infected leaves were collected both from sunny and shade part of the plants. The infection has been in the state of chlorotic spots formation on the upper side of the leaves, i.e. ca 7 days after inoculation (Cséfalvay et al., 2009). To avoid drying and to preserve the freshness of leaf samples, each petiole was coated by wet cellulose and transported immediately to 
the laboratory in plastic bags by using portable refrigeration unit, setted up to $15{ }^{\circ} \mathrm{C}$. In total, 30 samples have been collected, 15 healthy leaves and 15 infected leaves. Chlorophyll fluorescence and reflectance measurements as well as pigment analysis have been done on each collected leaf.

\section{Chlorophyll fluorescence measurements}

Chlorophyll fluorescence (Chl-F) measurements was done by using commercial kinetic imaging fluorometer (OpenFluorCam 70MF, Photon System Instruments, Brno, Czech Republic) in the laboratory directly situated in the vineyard. Before each measurement, grapevine leaves were dark adapted for 20min. Then, minimum Chl-F in dark $\left(\mathrm{F}_{0}\right)$ was determined using five measuring flashes generated by two panels of light-emitting diodes (LEDs, $\lambda_{\max }=635 \mathrm{~nm}$ ). Subsequently, short saturating flash $\left(1.500 \mu \mathrm{mol}\right.$ photons $\left.\mathrm{m}^{-2} \cdot \mathrm{s}^{-1}\right)$ was applied to measure maximum Chl-F in dark $\left(\mathrm{F}_{\mathrm{M}}\right)$. Saturating light was generated by $250 \mathrm{~W}$ white halogen lamp ( $\lambda=400-700 \mathrm{~nm}$ ). After following 15 $s$ of dark relaxation, samples have been exposed to actinic light $\left(200 \mu \mathrm{mol}\right.$ photons $\left.\mathrm{m}^{-2} \cdot \mathrm{s}^{-1}\right)$ and the Chl-F induction has been captured during which peak level of Chl-F reached after ca $1 \mathrm{~s}\left(\mathrm{~F}_{\mathrm{p}}\right)$ and steady state Chl-F level after $190 \mathrm{~s}$ of actinic light were measured. Chl-F transient was recorded by CCD camera in series of $512 \times 512$ pixel images of 12-bit resolution.

Chl-F parameters $\mathrm{F}_{0}, \mathrm{~F}_{\mathrm{M}}$, Fp, and $\mathrm{F}_{\mathrm{S}}$ values were determined. Then, three derived Chl-F parameters have been calculated: maximum quantum yield of PSII photochemistry $\left(\mathrm{F}_{\mathrm{V}} / \mathrm{F}_{\mathrm{M}}\right.$, Kitajima and Butler, 1975) according to following formula: $F_{V} / F_{M}=\left(F_{M}\right.$ $\left.\mathrm{F}_{0}\right) / \mathrm{F}_{\mathrm{M}} ; \mathrm{Fd}=\mathrm{F}_{\mathrm{P}}-\mathrm{F}_{\mathrm{S}}$ and time, in which $\mathrm{Fd} / 2$ has been reached. Distribution of Chl-F over the leaves as well as values of the Chl-F parameters of the healthy and infected leaf tissue have been inspected.

\section{Reflectance measurement}

Hemispherical, adaxial leaf reflectance measurements were carried out directly in vineyard using commercial optical spectrometer (Spectrometer SM 9000, Photon System Instruments, Brno, Czech Republic). The reflectance spectra $(400-800 \mathrm{~nm}$, lnm resolution) of healthy and infected leaf tissue were measured directly in vineyard by using leaf clip. For each sample, ten reflectance spectra were measured on different places over the leaf and averaged.

Followed vegetation reflectance indices $\left(\mathrm{R}_{85}\right.$ $\left.-\mathrm{R}_{710}\right) /\left(\mathrm{R}_{850}-\mathrm{R}_{680}\right.$ ) (Datt, 1999), $\mathrm{R}_{750} / \mathrm{R}_{700}$ (Gitelson and Merzlyak, 1994), $\left(\mathrm{R}_{780}-\mathrm{R}_{710}\right) /\left(\mathrm{R}_{780}-\mathrm{R}_{680}\right)$ (Maccioni at al., 2001) were calculated to estimate chlorophyll concentration; $C R I=R_{N I R}\left(1 / R_{510}-1 / R_{550}\right)\left(\lambda_{N I R}=760-\right.$ $800 \mathrm{~nm}$, Merzlyak et al., 2003) and CRII = $1 / \mathrm{R}_{510}-1$ / $\mathrm{R}_{700}$ (Gitelson et al., 2002) were calculated to estimate carotenoids concentration.

\section{Pigments determination}

Fresh leaf discs were cut from healthy leaves and infected spots in infected leaves and stored in liquid nitrogen. Then, the samples have been homogenized and pigments have been extracted using 100\% methanol. Small amount of $\mathrm{MgO}$ to prevent chlorophylls (Chl) degradation was added. Pigment contents have been determined spectroscopically, absorption spectra at wavelengths $470 \mathrm{~nm}, 652.4 \mathrm{~nm}$ and $665.2 \mathrm{~nm}$ have been measured using spectrophotometer (Spectrophotometer Lambda, PerkinElmer, Messatchusetts, USA). Chlorophyll-a, chlorophyll-b and total carotenoids concentrations were calculated according to Lichtenthaler (1987). The pigment content was expressed on a leaf area basis.

\section{RESULTS AND DISCUSSION}

\section{Chlorophyll fluorescence}

$\mathrm{F}_{\mathrm{V}} / \mathrm{F}_{\mathrm{M}}$ is frequently used Chl-F parameter for estimation plant-fungal interactions (e.g. Prokopová et al., 2010; Soukupová et al., 2003). Acording to Cséfalvay et al. (2009), we have used $\mathrm{F}_{\mathrm{V}} / \mathrm{F}_{\mathrm{M}}$ as the most effective parameters for an early detection of Plasmopara viticola infection. $\mathrm{F}_{\mathrm{V}} / \mathrm{F}_{\mathrm{M}}$ is parameter relating to photosynthetic activity of leaves (Kitajima and Butler, 1975). To verify $\mathrm{F}_{\mathrm{v}} / \mathrm{F}_{\mathrm{M}}$ effectiveness in field, we have analyzed all 30 collected leaves. Distribution of $\mathrm{F}_{\mathrm{V}} / \mathrm{F}_{\mathrm{M}}$ over the infected leaves compared to control ones is shown in Fig. 1. The infected leaf spots in which the fungal infection started to proceed expressed significantly lower $\mathrm{F}_{\mathrm{V}} / \mathrm{F}_{\mathrm{M}}$ in all measured susceptible varieties. Since Plasmopara viticola does not spread outside the inoculated area, the measured susceptible grapevine varieties do not mount systemic responses and the Chl-F does not change outside the spots of inoculation (Cséfalvay et al., 2009).

To compare to which extend is $\mathrm{F}_{\mathrm{v}} / \mathrm{F}_{\mathrm{M}}$ decreased in the infected leaf spots, we have extracted Ch-F only over the infected leaf spots and compare with those from controls. Fig. 1 shows the comparison of $F_{v} /$ $\mathrm{F}_{\mathrm{M}}$ from the healthy leaves and infected spots. In all control healthy leaves $\mathrm{F}_{\mathrm{V}} / \mathrm{F}_{\mathrm{M}}$ reached the maximum level, which is around 0.83 (Kitajima and Butler, 1975). On the contrary, infected spots expressed ca $25 \%$ lower $\mathrm{F}_{\mathrm{V}} / \mathrm{F}_{\mathrm{M}}$ values, which indicate damage of PSII reaction centers. Typically, $\mathrm{F}_{0}$ levels were higher while $\mathrm{F}_{\mathrm{M}}$ levels were lower in infected leaf spots (data not shown). Similarly, Mandal et al., (2009) observed higher $\mathrm{F}_{0}$ level in Plantago ovata Forsk leaves infected by downy mildew compared to control ones.

The induction kinetics of the Chl-F provides much more information about the primary photochemistry and show clear difference between the photochemistry in healthy and infected leaf tissue. Fig. 2A shows normalized Chl-F induction of healthy and infected leaf tissue of Cabernet Sauvignon. When the actinic light is switched on Chl-F starts to change. It increases from $F_{0}$ to $F_{P}$ 


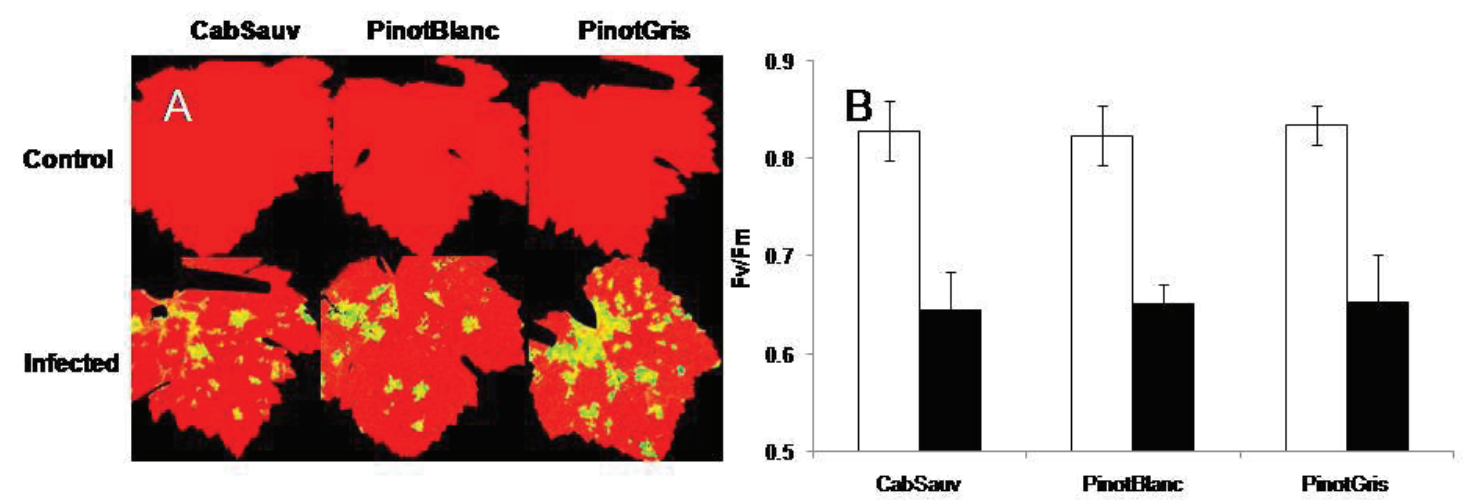

1: A: False scale colorimages of $F_{V} / F_{M}$ (maximum quantum yield of photosystem II) distribution over representative healthy (top panel) and infected (bottom panel) leaves of three susceptible grapevine varieties (Cabernet Sauvignon, Pinot Blanc and Pinot Gris)

B: Maximum quantum yield of photosystem II $\left(F_{V} / F_{M}\right)$ of healthy [ $\left.\square\right]$ and infected [ $[\mathbf{]}]$ leaf tissue of three sensitive grapevine varieties: Cabernet Sauvignon, Pinot Blanc and Pinot Gris. Columns show mean values for 5 controls and 5 infected leaves for each variety. Standard deviation (SD) shown both for control and infected leaves.
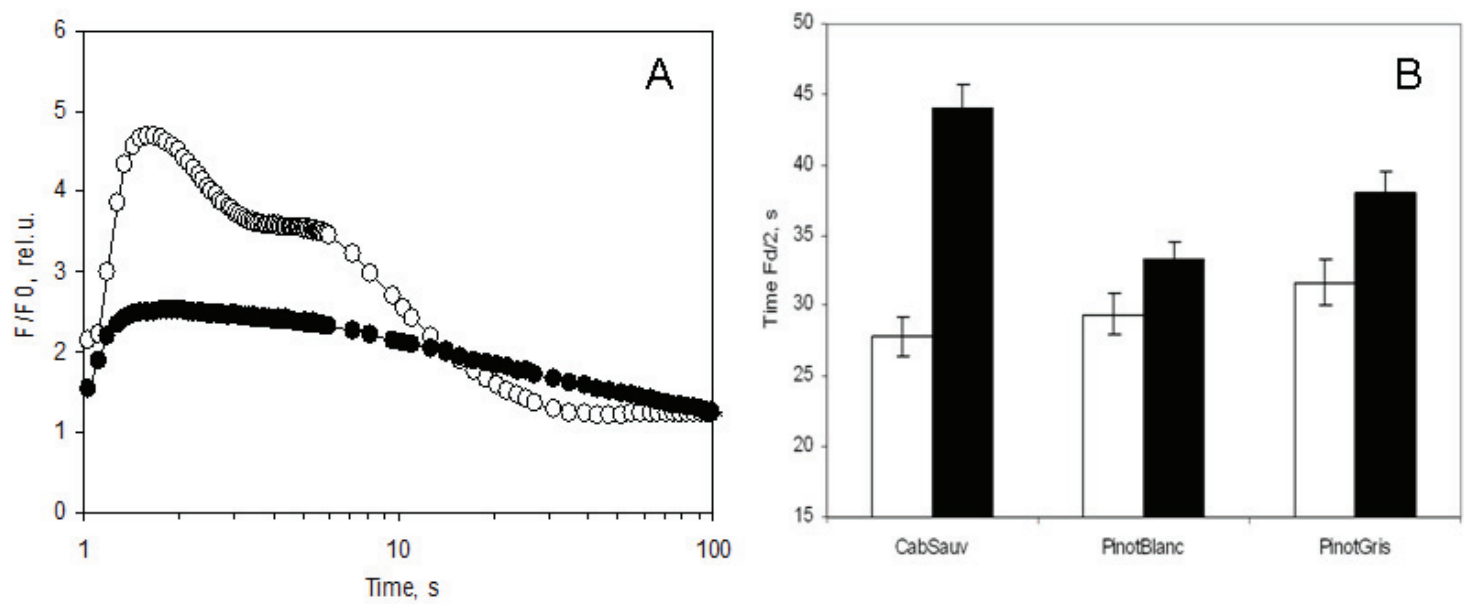

2: A: Chl-F induction kinetics of dark adapted Cabernet Sauvignon leaf tissue captured in vivo by using OpenFluorCam 70 MF. Chl-Finduction was recorded after 20 min of dark adaptation under actinic light $\left(200 \mu\right.$ mol(photons). $\left.\mathrm{m}^{-2} \cdot \mathrm{s}^{-2}\right)$. Mean values for control $[\circ]$ and infected $[\bullet]$ leaf tissue are normalized to the minimum Chl-F level in dark adapted state $\left(F_{0}\right)$, and presented in logarithmic timescale.

B: Difference between the time of reaching $\mathrm{Fd} / 2$ in dark adapted leaf tissue when exposed to actinic light (200 $\mu \mathrm{mol}($ photons $) \mathrm{m}^{-2} \mathrm{~s}^{-1}$ ). Healthy ( $\square$ ) and infected () leaves of three susceptible varieties were used (Cabernet Sauvignon, Pinot Blanc, Pinot Gris). Fd/2 is time, in which Chl-F of leaves reaches half of the difference between peak fluorescence emission $\left(F_{\mathrm{p}}\right)$ and steady state fluorescence emission $\left(F_{s}\right)$ $\left[F d / 2=\left(F_{P}-F_{S}\right) / 2\right]$. Columns represent mean values of 5 measurements \pm standard deviation.

within ca $1 \mathrm{~s}$, which represents changes on the electron donor site of PSII under actinic light. Then, Chl-F starts to decrease down to $\mathrm{F}_{\mathrm{S}}$ as the electrons are transported from the plastoquinone pool down to photosystem I (acceptor site of PSII).

Infected leaf spots expressed much slower increase of Chl-F, significantly lower $F_{P}$ and much slower decrease from $\mathrm{F}_{\mathrm{P}}$ down to $\mathrm{F}_{\mathrm{S}}$ (Fig. 2A) compared to healthy non-infected tissues. This kinetic expresses much slower electron transport rate both on donor and acceptor site of PSII, i.e. much slower photochemistry in infected leaf tissue. To evaluate how fast the electrons are transported from plastoquinone pool, we have compared the time, in which the Chl-F decrease from $F_{P}$ to $F_{S}$ reached the half value $-\mathrm{Fd} / 2$ (Fig. $2 \mathrm{~B}$ ).
Time of the Fd/2 was much longer in infected leaves (ca 32-45 s) indicating much slower electrons release from PSII and thus damage in PSII acceptor side compared to control non-infected ones (2532 s). One of the reasons could be decrease of chlorophyll-a concentration within infected leaf tissue (Tab. I).

\section{Pigment analysis}

The concentrations of the most abundant plant pigments chlorophyll a (Chla), chlorophyll b (Chlb), Chla/b ratio and carotenoids (Car) are summarized in Tab. I.

In photosynthesis, Chla is the most important pigment for light harvesting process and for the proper function of PSII reaction centers. In infected 
I: Pigment content (in $\mu \mathrm{g} \mathrm{cm}^{-2}$ ) and Chl a/b ratio in control leaves and leaf tissue naturally infected by Plasmopara viticola. Chl-a, Chl $a+b$ are contents of chlorophyll a, total chlorophyll a, respectively; Chla/b ratio is ratio between Chl-a and Chl-b content, and Car are total carotenoids (Cabernet Sauvignon, Pinot Blanc and Pinot Gris).

\begin{tabular}{|c|c|c|c|c|c|c|}
\hline & \multicolumn{2}{|c|}{ Chla } & \multicolumn{2}{|c|}{ Chla+b } & \multicolumn{2}{|c|}{ Chlab ratio } \\
\hline & Control & infected & Control & infected & Control & Infected \\
\hline Cabernet Sauvignon & $27.92 \pm 0.32$ & $1227 \pm 0.98$ & $36.87 \pm 0.55$ & $17.46 \pm 1.4$ & $3.07 \pm 0.03$ & $2.36 \pm 0.04$ \\
\hline Pinot Blanc & $21.12 \pm 0.53$ & $10.56 \pm 1.10$ & $27.96 \pm 0.26$ & $14.91 \pm 1.55$ & $3.08 \pm 0.54$ & $2.42 \pm 0.03$ \\
\hline \multirow[t]{3}{*}{ Pinot Gris } & $25.59 \pm 1.26$ & $13.86 \pm 0.51$ & $33.98 \pm 1.63$ & $19.55 \pm 0.73$ & $3.04 \pm 0.03$ & $2.44 \pm 0.03$ \\
\hline & \multicolumn{2}{|c|}{ Total carotenoids } & & & & \\
\hline & Control & Intected & & & & \\
\hline Cabernet Sauvignon & $2.45 \pm 0.33$ & $0.52 \pm 0.01$ & & & & \\
\hline Pinot Blanc & $1.63 \pm 0.03$ & $0.46 \pm 0.07$ & & & & \\
\hline Pinot Gris & $2.09 \pm 0.44$ & $0.42 \pm 0.11$ & & & & \\
\hline
\end{tabular}

leaf tissue was approximately half of the Chla concentration which explains much lower $\mathrm{F}_{\mathrm{v}} / \mathrm{F}_{\mathrm{M}}$ (Fig. 1) and slower electron transport rate (Fig. 2). Decrease of Chla concentration in the infected leaf tissue was ca 56\% (CS), 58\% (PB) and 45\% (PG). Similar results have been found in case of Chla+b and Chlb content. One must note that there was noticeable loss of greenness but no necrosis in the infected parts of leaves. Similarly to our findings, reduction of chlorophyll content during the Plasmopara viticola infection was observed by Jermini et al. (2010) and Lebeda et al. (2008) who found ca 50\% decrease of Chl $\mathrm{a}+\mathrm{b}$, too. Chla/b ratio was founded to be decreasing in all observed infected leaves (Tab. I). Compared to control leaves, where Chla/b ratio ranged from 2.99 to 3.12 in CS, 2.99 to 3.26 in PB and 2.98 to 3.14 in PG, $\mathrm{Chla} / \mathrm{b}$ ratio in infected leaves decreased up to range between 2.30 to 2.45 in CS, 2.35 to 2.49 in PB and 2.36 to 2.54 in PG. Depending on the stress, Chla/b ratio has been observed to be both increasing (e.g. Nanda and Biswal, 2008; Funayama et al., 1997) or decreasing in infected leaves (Farouk and Osman, 2011).

Plasmopara viticola infection resulted also in significantly lower Car content than in healthy, control leaves (Tab. I). The highest reduction ( 80\%) was observed in leaves of CS and PG, where Car content of infected leaves varying from 0.48 to

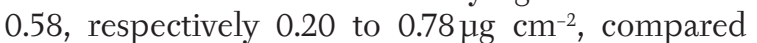
to control leaves, with the variation of Car content from 1.64 to 3.08 , respectively 1.15 to $2.35 \mu \mathrm{g} \mathrm{cm}{ }^{-2}$. Reduction of Car content of $\sim 70 \%$ founded in PB, where the concentration dropped from the range between 1.17 to $2.01 \mu \mathrm{g} \mathrm{cm} \mathrm{cm}^{-2}$ of control leaves to range between 0.35 to $0.74 \mu \mathrm{g} \mathrm{cm} \mathrm{cm}^{-2}$ in infected leaves, which corresponds to Car decrease in downy mildew resistant and susceptible genotypes of pearl millet (Mahatma et al., 2009).

\section{Reflectance measurement}

To explore also reflectance properties of the leaf tissue infected by Plasmopara viticola, we have measured reflectance spectra (400-800 nm) on leaves directly in vineyard. Fig. 3 represents reflectance spectrum of control and infected leaf tissue of Cabernet Sauvignon leaves. Similar results have been obtained from Pinot Gris and Pinot Blanc leaves. The reflectance spectrum of representative leaves (Fig. 3) is normalized to maximum reflectance in green region (550 nm), where Chl-a and Chl-b are absorbing minimally and Car do not absorb at all. Between control and infected leaves, we found visible difference in the region 550-700 $\mathrm{nm}$ and over $700 \mathrm{~nm}$. For accurate results, differences between reflectance spectra of control leaves and reflectance spectra of infected leaves have been calculated (data not shown). The difference in reflectance spectra (\%), showed the minimum variability in the region 400$500 \mathrm{~nm}$. In the range of reflectance between 505-515 $\mathrm{nm}$, first visible change connected to carotenoids content (Gitelson et al., 2002) was founded, followed by minimal changes in the region 515-545 $\mathrm{nm}$. Next significant difference between control and infected leaf reflectance spectrum has been found at $550 \mathrm{~nm}$, the wavelength with the maximum reflectivity of chlorophylls. In the region 550-700 $\mathrm{nm}$, differences are visible in the whole spectrum. Lower energy wavelength (700-900 nm) showed the most significant differences in 700, 750 and $850 \mathrm{~nm}$.

From the reflectance spectra we have derived particular vegetative indices with known physiological interpretation. VIs are mathematical transformations of reflectance at specifically selected spectral bands that maximize sensitivity to target biophysical variables and minimize confounding environmental factors (e.g., Myneni et al., 1995). Several VIs have been developed for remote quantification of leaf chlorophyll content $\left(\mathrm{Chl}_{\mathrm{a+b}}\right)$ (e.g., Le Maire et al., 2004) and/or other biophysical variables (e.g., Ustin et al., 2004) that are important for the assessment of the health status and functioning of terrestrial ecosystems. He have selected VIs to estimate chlorophyll content and 


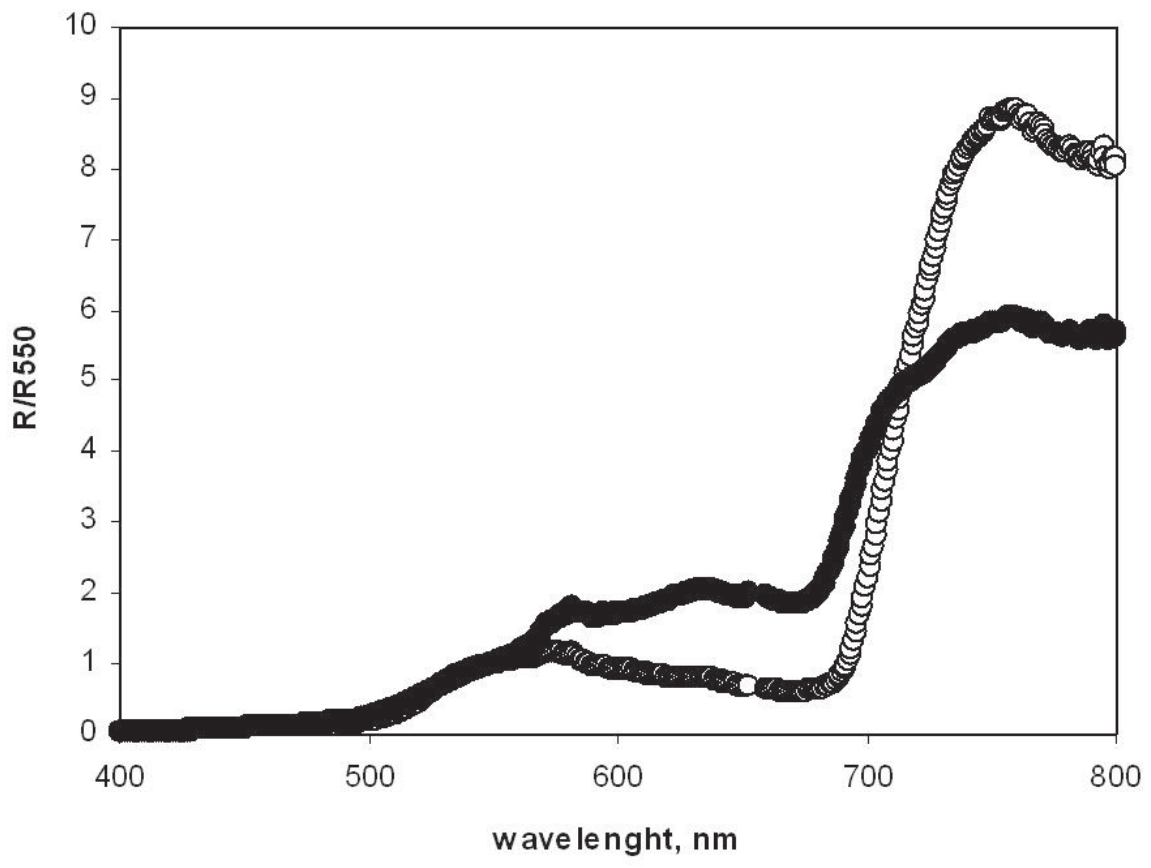

3: Adaxial reflectance spectra of representative leaves (Cabernet Sauvignon), collected in field, July 2011 measured by Spectrometer SM 9000, Photon System Instruments, Brno, Czech Republic. Each line represents mean of 10 measurements of individual leaf normalized to reflectance in $550 \mathrm{~nm}\left(R / R_{550}\right)$ both for control [o] and infected [•] leaf tissue.
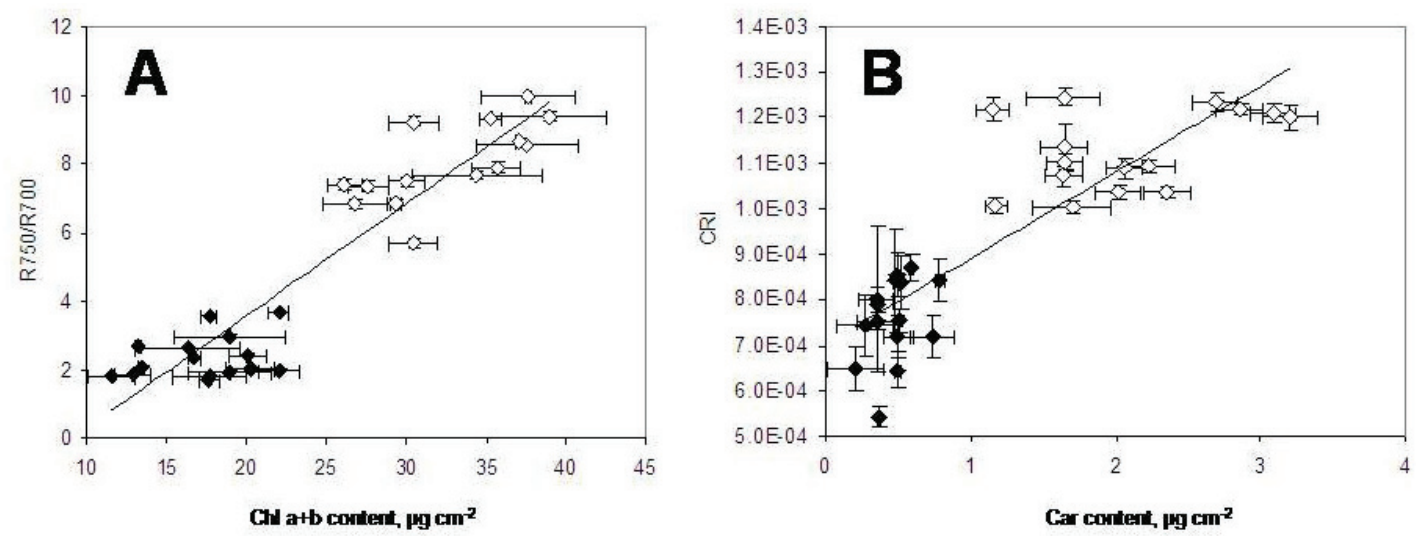

4: Linear correlation of reflectance vegetation indices and photosynthetic pigment contents: R750/R700 vs. chlorophylls (panel A), CRI vs. carotenoids (panel B). Symbols are mean values for 45 measurements of control healthy grapevine leaf tissue [o], 45 measurements for infected leaf tissue [•] of three susceptible varieties (Cabernet Sauvignon, Pinot Blanc and Pinot Gris). Correlation points are interleaved by linear trendline with characteristic: Panel $A\left(y=0.3272 x-2.9704 ; R^{2}=0.8769\right)$, Panel $B\left(y=0.0002 x+0.0007 ; R^{2}=0.7352\right)$. Vegetation indices were calculated from mean reflectance spectrum for each single leaf, and correlated with pigment analysis of each single leaf. Chl $\mathrm{a}+b$ and Car content is expressed in $\mu \mathrm{g} \mathrm{cm}^{-2}$. The interpolating line represents a linear regression optimized by MS Excel.

carotenoids content and correlated their values with the analyzed pigments content.

In case of chlorophylls, the highest correlation coefficient $\left(R^{2}=0.8769\right.$, Fig. 4A) was found for VI R750/R700 (Gitelson and Merzlyak, 1994). This VI clearly discriminated the infected leaves with lower chlorophyll content from the control ones. Several known carotenoids indices were inspected to discriminate carotenoids content in control and infected leaves, too. The highest correlation coefficient displayed CRI vegetation index (Fig. 4B, Merzlyak et al., 2003). Both chlorophyll (R750/ R700) and CRI values increased with increased concentration of pigments (Fig. 4A and B). Hence they were able to discriminate healthy leaf tissue with higher pigment content and infected leaf tissue with lower pigment content. 


\section{CONCLUSIONS}

In this study we aimed at response of grapevine leaves naturally infected by Plasmopara viticola measured by means of Chl-F and reflectance. Infected leaves have impaired function of photosynthetic apparatus resulting in lower $\mathrm{F}_{\mathrm{V}} / \mathrm{F}_{\mathrm{M}}$ and longer time in which $\mathrm{Fd} / 2$ is reached. We have verified that Chl-F parameter related to photosynthetic activity $\left(\mathrm{F}_{\mathrm{V}} / \mathrm{F}_{\mathrm{M}}\right)$ is effective to discriminate healthy and naturally infected leaf tissue in susceptible grapevine varieties (Cabernet Sauvignon, Pinot Blanc and Pinot Gris). Heterogenous distribution of $\mathrm{F}_{\mathrm{v}} / \mathrm{F}_{\mathrm{M}}$ over infected leaf tissue can play an important role for detection of infection, as well as it can be a diagnostic tool for an early detection of infection (Cséfalvay et al., 2009). On the other hand, time of Fd/2 can play some role in remote sensing on the canopy level and localization of infected plants by using 3 spatial dimensions (Bellasio et al., 2012) since it does not require saturating flashes.

Reflectance indices followed the variations in pigment content after the fungal infection. Among others, R750/R700 and CRI were the most potent to follow changes in chlorophylls and carotenoids contents, respectively. We can conclude that these indices can be used as a remote sensing tool to follow pigment changes in vineyards after Plasmopara viticola infection. More work should be done to test the algorithms in resistant grapevine varieties (e.g. Laurot, Malverina, Cerason, Hibernal).

\section{Acknowledgement}

This study was funded by the Grant Agency of the Czech Republic, grant No. 525/09/0365, and by CzechGlobe - Centre for Global Climate Change Impacts Studies, Reg. No. CZ.1.05/1.1.00/02.0073. The collective of authors thank to Michal Kř́ha for help with sampling during the summer academic course 2011.

\section{REFERENCES}

BARBAGALLO, R. P., OXBOROUGH, K., PALLET, K. E., BAKER, N. R., 2003: Rapid, noninvasive screening for pertubations of metabolism and plant growth using chlorophyll fluorescence imaging. Plant Physiol., 132: 485-493.

BELLASIO, CH., OLEJNÍČKOVÁ, J., TESAŘ, R., ŠEBELA, D., NEDBAL, L., 2012: Computer reconstruction of plant growth and chlorophyll fluorescence emission in 3 spatial dimensions. Sensors, 12(1): 1052-1071.

BJORN, L. O., PAPAGEORGIOU, G. C., BLANKENSHIP, R. E., GOVINDJEE, 2009: A viewpoint: why chlorophyll a? Photosynth. Res., 99: 89-98.

BLACKBURN, G. A., 2007: Hyperspectral remote sensing of plant pigments. J. Exp. Bot., 58(4): 855867.

BLACKBURN, G. A., FERWERDA, J. G, 2008: Retrieval of chlorophyll concentration from leaf reflectance spectra using wavelet analysis. Remote Sens.Env., 112: 1614-1632.

CSÉFALVAY, L., DI GASPERO, G., MATOUŠ, K., BELLIN, D., RUPERTI, B., OLEJNÍČKOVÁ, J., 2009: Pre-symptotic detection of Plasmopara viticola infection in grapevine leaves using chlorophyll fluorescence imaging. Eur. J. Plant Pathol., 125: 291302.

DATT, B., 1999: Visible/near infrared reflectance and chlorophyll content in Eucalyptus leaves. Int. J. Remote Sens., 20(14): 2741-2759.

DAVIES, M. K., 2004: Plant pigments and their manipulation. Annual plant reviews. Blackwell Publishing, vol. 14, Oxford-Boca Raton, 2004.

DIEZ-NAVAJAS, A. M, WIEDEMANN-MERDINOGLU, S., GREIF, C., MERDINOGLU, D., 2008:
Nonhost versus Host resistance to the grapevine Downy Mildew, Plasmopara viticola, studied at tissue level. Phytopatology, 98(7): 776-780.

FAROUK, S., OSMAN, M. A., 2011: The effect of plant defense elicitors on common bean (Phaseolus vulgaris L.) growth and yield in absence or prsence of spider mite (Tetranychus urticae Koch) infestation. J. Stress Physiol. Biochem., 7(3): 5-22.

FILELLA, I., PORCAR-CASTELL, A., MUNNEBOSCH, S., BACK, J., GARBULSKY, M. F., PENUELAS, J., 2009: PRI assessment of longterm changes in carotenoid/chlorophyll ratio and short-term changes in de-epoxidation state of the xanthophyll cycle. Int. J. Remote Sens., 30: 44434455.

FUNAYAMA, S., SONOIKE, K., TERASHIMA, I., 1997: Photosynthetic properties of leaves of Eupatorium makinoi infected by a geminivirus. Photosynth. Res., 53:253-261.

GITELSON, A., 1992: The peak near 700nm on radiance spectra of algae and water: relationship of its magnitude and position with chlorophyll concentration. Int. J. Remote Sens., 17 (13): 33673373.

GITELSON, A., MERZLYAK, M. N., 1994: Spectral reflectance changes associated with autumn senescence of Aesculus hippocastanum L. and Acer platanoides L. leaves. Spectral features and relation to chlorophyll estimation. J.Plant Physiol., 143: 286292.

GITELSON, A. A., MERZLYAK, M. N., YURI, G., 1996: Novel algorithms for remote sensing of chlorophyll content in higher plant leaves. Geoscience and Remote Sens. Symposium, 4: 2355-2357. GITELSON, A. A., MERZLYAK, M. N., CHIVKUNOVA, O. B., 2001: Optical properties 
and nondestructive estimation of anthocyanin content in plant leaves. Photochem. and Photobiol., 74(1): 38-45.

GITELSON, A. A., ZUR, Y., CHIVKUNOVA, O. B., MERZLYAK M. N., 2002: Assesing Carotenoid content in plant leaves with reflectance spectroscopy. Photochem. Photobiol., 75(3): 272-281.

JERMINI, M., BLAISE, P., GESSLER, C., 2010: Influence of Plasmopara viticola on gas exchange parameters on field-grown Vitis vinifera Merlot. Vitis, 49(2): 87-93.

JIANG, Y., CARROW, R. N., 2005: Assesment of narrow-band canopy spectral reflectance and turfgrass performance under drought stress. Hort Science, 40(1): 242-245.

KITAJIMA, M., BUTLER, W. L., 1975: Quenching of Chlorophyll fluorescence and photochemistry in chloroplasts by dibromothymoquinone. Biochem. et Biophys. Acta (BBA)-Bioenergetics, 376(1): 105-115.

KORTEKAMP, A., ZYPRIAN, E., 2003: Characterization of Plasmopara- resistance in grapevine using in vitro plants. J. Plant. Physiol., 160: 1393-1400.

LAFON, R., CLERJEAU, M. (ED.), 1988: Downy mildew. Compedium of grape diseases. APS Press, Minesota, pp. 11-13.

LEBEDA, A., SEDLÁŘOVÁ, M., PETŘIVALSKÝ, M., PROKOPOVÁ, J., 2008: Diversity of defence mechanisms in plant-oomycete interactions: a case study of Lactuca spp. and Bremia lactucae. Eur. J. Plant Pathol., 122: 71-89.

LEBEDA, A., SPENCER-PHILLIPS, P. T. N., COOKE, B. M., 2008: The downy mildew-Genetics, molecular biology and control. Eur. J. Plant Pathol., 122(1): 3-18.

LE MAIRE, G., FRANCOIS, C., DUFRENE, E., 2004: Towards universal broad leaf chlorophyll indices using prospect simulated database and hyperspectral reflectance measurements. Remote Sens Environ, 89: 1-28.

LICHTENTHALER, H. K., 1987: Chlorophylls and carotenoids: pigments of photosynthetic biomembranes. Methods enzymol., 148: 350-382.

LICHTENTHALER, H. K., BABANI, F., LANGSDORF, G., 2007: Chlorophyll fluorescence imaging of photosynthetic activity in the sun and shade leaves of trees. Photosynth. Res., 93: 235-244.

LODISH, H., BERK, A., LAWRENCE ZIPURSKY, S., MATSUDAIRA, P., BALTIMORE, D., DARNELL, J., 2000: Molecular cell biology, $4^{\text {th }}$ edition. W.H. Freeman, New York.

MACCIONI, A., AGATI, G., MAZZINGHI, P., 2011: New vegetation indices for remote measurement of chlorophylls based on leaf directional reflectance spectra. J. Photochem. Photobiol., 61(1-2): 52-61.

MAHATHAMA, M. K., BHATNAGAR, R., DHANDHUKIA, P., THAKKAR, V. R., 2009: Variation in metabolites constituent in leaves of downy mildew resistant and susceptible genotypes of pearl millet. Physiol. Mol. Biol. Plants, 15(3): 249-255.

MANDAL, K., SARAVANAN, R., MAITI, S., KOTHARI, I. L., 2009: Effect of downy mildew disease on photosynthesis and chlorophyll fluorescence in Plantago Ovata Forsk. J. of Plant diseases and Protection, 116(4): 164-168.

MAXWELL, K., JOHNSON, G. N., 2000: Chlorophyll fluorescence-a practical quide. J. Exp. Bot., 345(51): 659-668.

MERZLYAK, M. N., CHIVKUNOVA, O. B., 2000: Light-stress-induced pigment changes and evidence for anthocyanin photoprotection in apples. J. Photochem. Photobiol. B. Biol., 55: 155-163.

MERZLYAK, M. N., GITELSON, A. A., CHIVKUNOVA, O. B., SOLOVCHENKO, A. E., POGOSYAN S. I., 2003: Application of reflectance spectroscopy for analysis of higher plant pigments. Russ. J. Plant Physiol., 50(5): 704-710.

MERZLYAK, M. N., GITELSON, A. A., POGOSYAN, S. I., CHIVKUNOVA, O. B., LEHIMENA, L., GARSON, M., BUZULUKOVA, N. P., SHEVYREVA, V. V., RUMYANSTEVA, V. B., 1997: Reflectance spectra of leaves and fruits during their development and senescence under stress. Russ. J.Plant Physiol., 4(5): 614-622.

MORINODO, M., ORLANDINI, S., GIUNTOLI, A., BINDI, M., 2005: The effect of Downy and Powdery Mildew on grapevine (Vitis vinifera L.) leaf gas exchange. J. Phytopathology, 153:350-357.

MYNENI, R. B., HALL, F. G., SELLERS, P. J., MARSHAK, A. L., 1995: The interpretation of spectral vegetation indexes. IEEE Trans Geosci Remote Sensing, 33: 481-486.

NANDA, R. M., BISWAL, B., 2008: Biotic stress induced demolition of thylakoid structure and loss in photoelectron transport of chloroplasts in papaya leaves. Plant Physiol. Biochem., 46: 461-468.

NEDBAL, L., WHITMARSH, J., 2004: Chlorophyll fluorescence imaging of leaves and fruits. In: Papageorgiu, G. C., Govinjee. (ed.): Chlorophyll a fluorescence" A signature photosynthesis. Pp. 389-407. Springer, Dodrecht - Netherlands.

OXBOROUGH, K., 2004: Imaging of chlorophyll a fluorescence: theoretical and practical aspects of an emerging technique for the monitoring of photosynthetic performance. J. Exp. Bot., 400(55): 1195-1205.

PAPAGEORGIOU, G. C., GOVINJEE (ED.), 2004: Chlorophyll a Fluorescence: A signature of Photosynthesis.- Springer, Dodrecht - Netherlands.

PAPAGEORGIU, G. C., GOVINJEE, 2011: Photosystem II Fluorescence: Slow changes -scaling from the past. J. Photochem. Photobiol. B: Biol., 1-13.

PROKOPOVÁ, J., ŠPUNDOVÁ, M., SEDLÁŘOVÁ, M., HUSIČKOVÁ, A., NOVOTNÝ, R., DOLEŽAL, K., NAUŠ, J., LEBEDA, A., 2010: Photosynthetic response of lettuce to downy mildew infection and cytokinin treatment. Plant Physiol. Biochem., 48: 716-723.

ROHÁČEK, K., 2002: Chlorophyll fluorescence parameters: the definitions, photosynthetic meaning, and mutual relationship. Photosynthetica, 40(1): 13-29.

ROHÁČEK, K., SOUKUPOVÁ, J., BARTÁK, M., 2008: Chlorophyll fluorescence: A wonderfull tool 
to study plant physiology and plant stress. Plant Cell Compartment- Selected topics, 41-104.

ROLFE, S. A., SCHOLES, J.D., 2010: Chlorophyll fluorescence imaging of plant-pathogen interactions. Protoplasma, 247: 163-175.

ROMMER, CH., BURLING, K., HUNSCHE, M., RUMPF, T., NOGA, G., PLUMER, L., 2011: Robust fitting of fluorescence spectra for pre-symptomatic wheat leaf rust detection with Support Vector Machines. Comp. and El.in Agr., 79: 180-188.

SOUKUPOVÁ, J., SMATANOVÁ, S., NEDBAL, L. JEGOROV, A., 2003: Plant response to destruxins visualized by imaging of chlorophyll fluorescence. Physiologia Plantarum, 118: 399-405.

USTIN, S. L, ROBERTS, D. A, GAMON, J. A, ASNER, G. P, GREEN, R. O., 2004: Using imaging spectroscopy to study ecosystem processes and properties. Bioscience 54: 523-534.

WU, CH., NIU, Z., TANG, Q., HUANG, W., 2008: Estimating chlorophyll content from hyperspectral vegetation indices: Modelling and validation. Agric. Forest Met., 148: 1230-1241.

Address

Ing. David Šebela, Laboratoř ekologické fyziologie rostlin, Centrum výzkumu globální změny AV ČR, v.v.i., Bělidla 986/4a, 60300 Brno, Ústav fyziky a biofyziky, Přírodovědecká fakulta, Jihočeská univerzita v Českých Budějovicích, Branišovská 31, 37005 České Budějovice, Česká republika, Mgr. Julie Olejníčková, Ph.D., Laboratoř ekologické fyziologie rostlin, Centrum výzkumu globální změny AV ČR, v.v.i., Bělidla 986/4a, 60300 Brno, Česká republika, Mgr. Anita Župčanová, Ústav fyziky a biofyziky, Př́rodovědecká fakulta, Jihočeská univerzita v Českých Budějovicích, Branišovská 31, 37005 České Budějovice, Česká republika, Ing. Radek Sotolář, Ph.D., Ústav vinohradnictví a vinařství, Mendelova univerzita v Brně, Valtická 337, 69144 Lednice, Česká republika, e-mail: sebela@nh.cas.cz, olejnickova.j@czechglobe.cz, xsotolar@node.mendelu. 
